\title{
Hydraulic stream network conditioning by a tectonically induced, giant, deep-seated landslide along the front of the Apennine chain (south Italy)
}

\author{
A. Galeandro ${ }^{1}$, A. Doglioni ${ }^{1}$, A. Guerricchio ${ }^{2}$, and V. Simeone ${ }^{1}$ \\ ${ }^{1}$ Technical University of Bari, Department of Civil Engineering and Architecture, via E. Orabona 4, 70125 Bari, Italy \\ ${ }^{2}$ University of Calabria, Engineering Faculty, via P. Bucci, 87036 Arcavacata di Rende, Italy \\ Correspondence to: A. Galeandro (annalisa.galeandro@poliba.it)
}

Received: 28 May 2012 - Published in Nat. Hazards Earth Syst. Sci. Discuss.: Revised: 18 March 2013 - Accepted: 26 March 2013 - Published: 17 May 2013

\begin{abstract}
The tectonic stresses that produced the uplift of Apennine chain ridge in southern Italy generated advanced buried thrusts of allochthonous deposits that induced deformations of foredeep deposits. This thrust may cause giant, deep-seated landslides at the front of the chain. Starting from a specific case history in low Biferno Valley, this work presents how giant, deep-seated landslides along the front of the chain may be generated by the thrust of allochthonous nappe of the chain. In addition, the influence that these huge phenomena may have on landslide and flood susceptibility and on natural hazards of the involved area is analysed.

The work presents an interpretation of local morphology and stream network paths of low Biferno Valley as a consequence of a giant, deep-seated landslide affecting the right side of the valley. The proposed interpretation is supported by numerical geomorphological analyses of the area at stake. It is shown how both the morphologies of the catchments of the river Biferno and its tributary Cigno and stream paths are strongly conditioned by this large, deep-seated landslide. This landslide deviates the stream paths affecting both the flooding susceptibility of low Biferno Valley and landslide susceptibility on the left side of Biferno Valley.
\end{abstract}

\section{Introduction}

At the transition zone between the geodynamic domains of chain and foredeep-foreland region, the orogenesis produced severe deformations of the internal boundary of foredeep deposits as a consequence of thrusting of allochthonous nappes under these deposits (Fig. 1). Therefore the thrusting induced by tectonics and the related deformations strongly influence geomorphology of these areas and can constitute an important predisposing factor for landslides involving deformed foredeep deposits, and for giant landslides sliding along the buried front of the chain (Fig. 1). These landslides can permanently condition river stream paths as well as flooding and landslide susceptibility in large areas (Corsini et al., 2009). The large-scale analysis and interpretation of the landforms can be functional to recognize and describe the complex geological and geomorphological structure somehow concealed with these kind of huge landslides. It can be of general interest, not only useful for understanding specific geomorphological features and processes, but also for looking at environmental planning.

The relationship between large landslide and tectonic uplift was broadly investigated in the past. Savage and Varnes (1987) and Hutchinson (1988) emphasized the dependence of large landslides on tectonic activity, which could provide significant changes of stress status and of rock properties as deep weathering and fatigue (Brückl, 2001). The study of the effects of deep-seated landslides has been pursued by several authors according to different approaches and purposes (Baron et al., 2005; Brückl and Parotidis, 2005; Dewitte et al., 2006). Structural and tectonic features may seriously affect the mechanism of failure of slopes (Alexander and Formichi, 1993; Guzzetti et al., 1996; Crosta and Clague, 2009), as described by different authors, assuming structural characteristics as important aggravating factors of failures and landslides (Guerricchio and Melidoro, 1981; Dramis and 

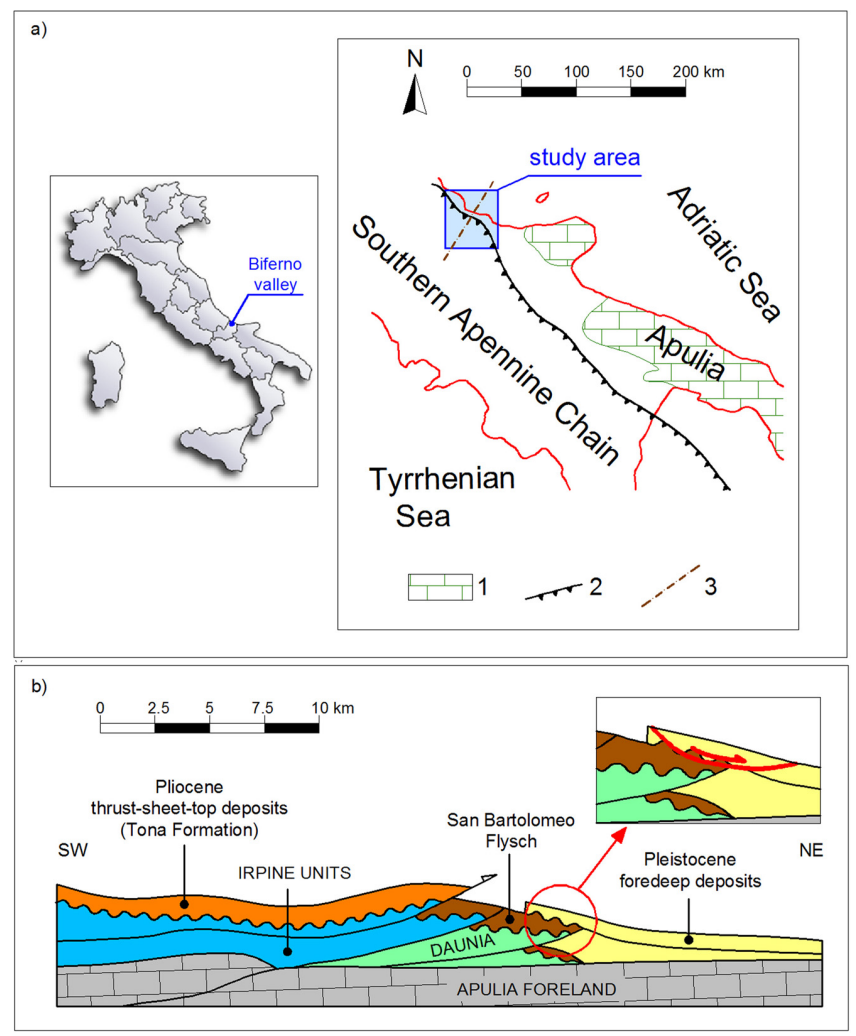

Fig. 1. (a) Structural sketch of central-southern Italy: 1 - MesozoicTertiary carbonates of the foreland areas; 2 - front of Apennines (after Patacca and Scandone, 2007, adapted and redrawn); 3 - outline of schematic geological cross section. (b) Schematic geological cross section and geological relationships between the tectonic units of the southern Apennines in Molise/Sannio region (after Patacca and Scandone, 2007, adapted and redrawn).

Sorriso-Valvo, 1994; Guerricchio et al., 1996; Kellogg, 2001; Rapisarda, 2007; Koukis et al., 2009; Jaboyedoff et al., 2009; Guerricchio et al., 2012).

Here on the base of a specific case study, it is presented how along the front of the Apennine chain, in a zone characterized by tectonic deformations due to underthrusting of allochthonous clay shales nappe, giant, deep-seated landslides can be activated in foredeep deposits due to the pushing and uplift effect due to tectonic thrusts. They can induce movements of foredeep deposit masses along the contact with allochthonous thrust, generating large landslides. One of these landslides is here identified in Biferno Valley and analysed in terms of effects on surface dynamics of large areas, thus conditioning their hazard.

The study particularly focuses on the case study of low Biferno Valley (south Italy), at the transition zone between Apennine chain and Adriatic foredeep domains (Figs. 1 and 2), where allochthonous nappes create blind thrust in Pleistocene foredeep deposits (Figs. 1 and 2) due to Apennine orogenesis. The morphological and geological characteristics of the valley as well as the paths and flow character- istics of rivers Biferno and Cigno are analysed by an analysis of a medium-resolution ( $40 \mathrm{~m}$ square cells), grid-based digital terrain model (DTM). The particular geomorphological features on the right side of the valley are interpreted as a consequence of a giant, deep-seated landslide, identified according to a geological interpretation of the surficial shapes. The presented interpretations are supported by specific numerical geomorphic analyses. Finally, the work focuses on how the identified large, deep-seated landslide affects the hydraulic and landslide susceptibility of low Biferno Valley (Guerricchio et al., 2010).

\section{General settings}

The complex thrust belt system of the Apennine chain is due to the compression towards NE of internal nappes of ancient Mesozoic carbonate platforms and flysch deposits (Ippolito et al., 1975; Patacca and Scandone, 2007). The studied area is located along the external eastern side of the chain at the passage from chain to foredeep domain, where Apennine allochthonous nappes thrust under Plio-Pleistocene foredeep deposits (Fig. 1) tilting and deforming foredeep deposits (Rapisardi, 1978; Aucelli et al., 1997; Aucelli and Rosskopf, 2000; Amorosi et al., 2009).

\subsection{Stratigraphy}

A simplified geological map of the study area (Fig. 2) is here constructed, based on the Geological Map of Italy (19621963) and of the Geological Map of Molise (Vezzani et al., 2004, 2010). The outcropping geological units are the following:

1. Allochthonous units:

- Sicilide units and S. Bartolomeo Flysch (Cretaceous-Miocene, C);

- Faeto Flysch (Daunia Flysch) (lower Miocene, M);

- Tona formation (lower Pliocene, PM);

2. Foredeep sub-Apennine grey-blue clays (late Pliocene-Pleistocene, Pa);

3. Regressive deposits (Pleistocene, Qr);

4. Alluvial deposits (Holocene, q).

The allochthonous units refer to the internal nappes, which involve variegated clay shales of Sicilide units (CretaceousEocene), the arenaceous flysch (S. Bartolomeo Flysch) and the marly-calcareous flysch (Faeto Flysch) of Irpinian units (Miocene) and the clayey and sandy conglomeratic units of Tona formation (lower Pliocene). According to Lanzafame and Tortorici (1976), Sicilide complex includes the sedimentary sequence deposed on the internal subsident trough. 


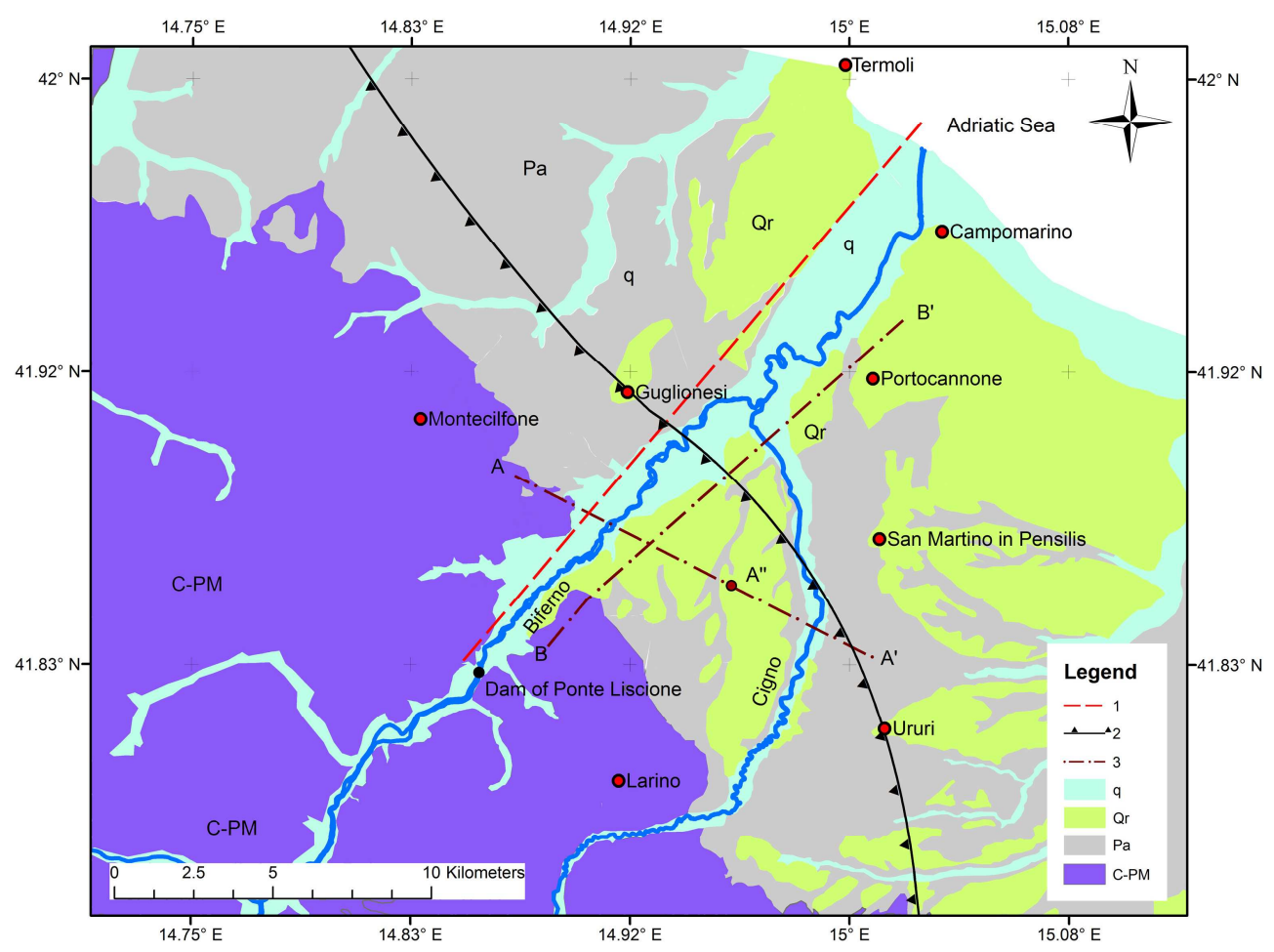

Fig. 2. Simplified geological map of the lower Biferno Valley (adapted from Geological Map of Italy, pp 154 and 155 ): 1 - transcurrent fault; 2 - buried front of Apennine allochthonous nappe (Structural Model of Italy - CNR, 1992); 3 - geological cross sections; q - recent alluvium (Holocene); Qr - regressive and continental deposits (Pleistocene); Pa - foredeep deposits, sub-Apennine grey-blue clays (late Pliocene-Pleistocene); C-PM - Apennine allochthonous nappe (Cretaceous-lower Pleistocene).

This is made up of variegated clays (Upper CretaceousOligocene), involving a lower pelitic member (variously coloured clays with chaotic bedding and markedly splintery texture) and an upper calcareous member, limestones with thin-bedded pelitic intercalations (AGI, 1985; Cotecchia et al., 1992). Irpinian units include the turbidite arenaceous sequence (S. Bartolomeo Flysch, Miocene) and calcareous sequence (Faeto Flysch, lower Miocene). S. Bartolomeo Flysch is characterized by two members: the earlier involves argillaceous marls and rare sandstones; the latter involves graded sandstones showing thick layers with lenses of conglomerates and levels of blue-grey pelites. The calcareous sequence (Faeto Flysch, lower Miocene) is constituted of densely alternated limestones, marly limestones, calcarenites, marls and clayey marls and sometimes bentonite clay levels, mainly white-grey coloured (Lanzafame and Tortorici, 1976). The allochthonous nappe is completed by Tona formation of lower Pliocene age, composed of a base conglomerate level covered by a clayey member and a regressive sandy-conglomerate member.

Foredeep Apennine deposits involve grey-blue clays and marly clays often interbedded by sand, locally named Montesecco Clay (Geological Map of Italy, 1962-1963; Bracone et al., 2012a, b; Festa et al., 2006). A detailed description and characterization of Montesecco clay is in Bracone et al. (2012b). These clays are covered by regressive (Serracapriola Sands and Campomarino Conglomerates, Pleistocene) and alluvial terraced deposits. A detailed description of these deposits is in Amorosi et al. (2009) and in Brancone et al. (2012a) These outcrop along the crest of San Martino in Pensilis and Ururi and along the slope toward river Saccione on the right side of the crest. The sequences of foredeep and regressive deposit are characterized by low inclination toward NE $\left(5-8^{\circ}\right)$ as a consequence of the deformation due to tectonic uplift (Rapisardi, 1978; Structural Model of Italy, 1992; Aucelli et al., 1997; Amorosi et al., 2009). A stratigraphic sequence of Montesecco clay, covered by sandy-gravelly soil deposits quite similar to the previous one, crops out at Larino Plateau, even if there is a difference in ground elevation of more than $100 \mathrm{~m}$ with a really steep scarp separating San Martino in Pensilis crest from the plateau (Fig. 3). In the plateau, these deposits are characterized by really low inclination up to $3^{\circ}$.

Finally, recent alluvial deposits (Holocene), characterized by detritus clayey-silty-sandy alluvial terrains, outcrop at the base on the valley.

\subsection{Tectonic and structural history}

Most of the current configuration of southern Apennine dates back to the Quaternary, when the mountain chain was 


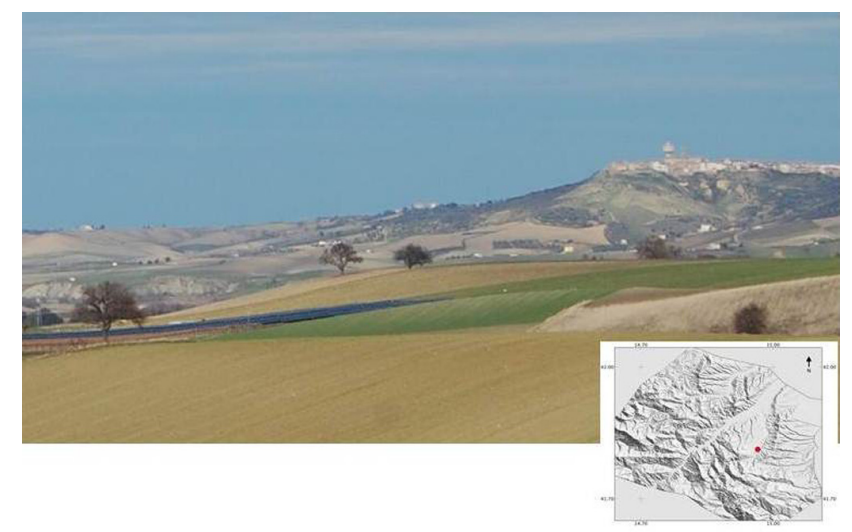

Fig. 3. View of the steep scarp downslope of the town of San Martino in Pensilis. In the lower right-hand corner, the position from which the photo was taken is shown.

affected by the last phases of the tectonic transport, with an intense tectonic uplift, which shifted Apennine nappes towards Bradanic foreland (Lanzafame and Tortorici, 1976; Pizzi, 2003; Ascione et al., 2008) giving the present geostructural layout to the Apennine. The tectonic uplift created also deformations of foredeep deposit at the front of the chain (Rapisardi, 1978; Structural Model of Italy, 1992; Aucelli et al., 1997; Amorosi et al., 2009) due to the stress induced by the Apennine chain thrust. A detailed analysis of the different phases of the tectonic uplift is described, among others, in Patacca and Scandone (2007), Vezzani et al. (2010), and Ascione et al. (2008). The average Quaternary uplift rates during the Holocene vary from a minimum of $0.15 \mathrm{~mm} \mathrm{yr}^{-1}$ to a maximum of $1.41 \mathrm{~mm} \mathrm{yr}^{-1}$, while for the last glacial cycle are equal to $+0.16 /+0.60 \mathrm{~mm} \mathrm{yr}^{-1}$ (Lambeck et al., 2010). Along the Adriatic coast next to Biferno catchment, Doglioni et al. (1996), quoted an uplift rate of about $0.5 \mathrm{~mm} \mathrm{yr}^{-1}$ during the Middle Pleistocene, while during the Upper Pleistocene, Pizzi (2003) quoted and uplift rate of about $0.2 \mathrm{~mm} \mathrm{yr}^{-1}$. Due to tectonic thrust locally the uplift could be even higher, particularly along the buried front of the thrust.

The joint effects of the sea level drawdown due to glaciations and the tectonic uplift may have conditioned the deepening of the hydrographic network (Galadini, 2006). The joint effects of hydrographic network deepening and of thrust-induced deformations may have caused instability phenomena involving foredeep deposits sliding at the contact between foredeep and allochthonous deposits that is characterized by low strength conditioning the morphologies of the valleys and their flank.

\subsection{Geomorphological description}

The upstream part of Biferno catchment develops through Apennine chain, and it has a quite irregular morphology, characterized by steep slopes and by scarps and crests of

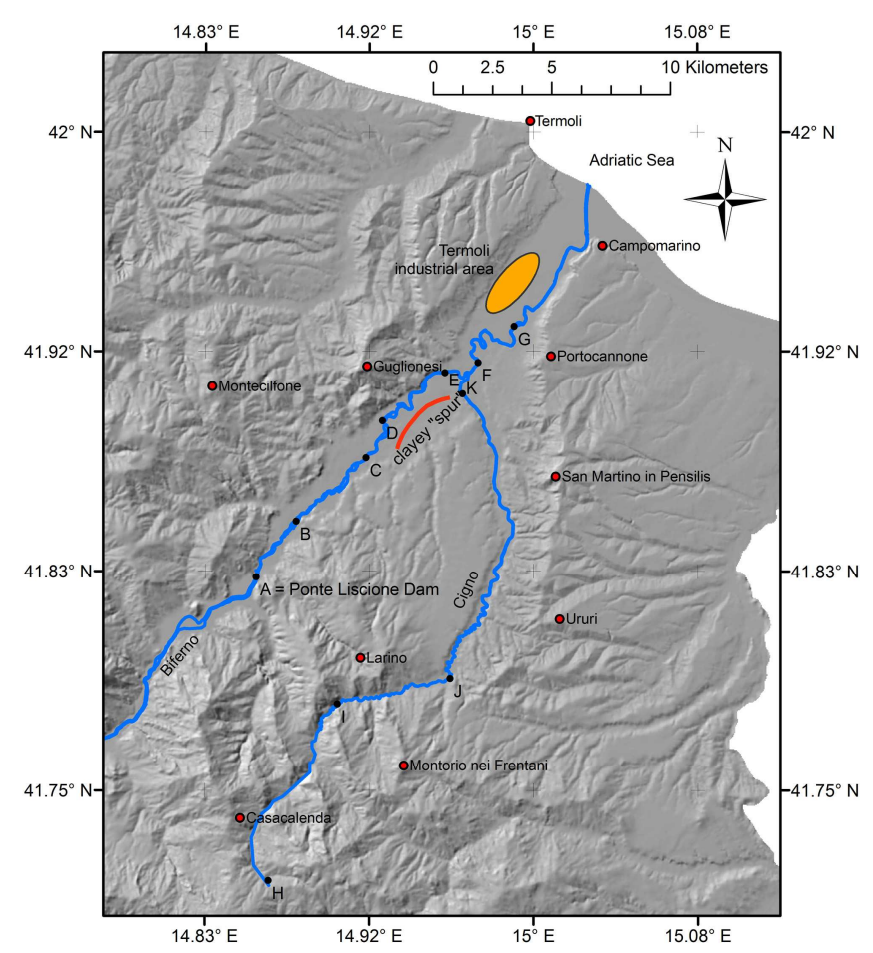

Fig. 4. Lower Biferno Valley study area on DTM with the evidence of different 2 reaches of the Biferno river downstream of the dam of Ponte Liscione and of the Cigno stream.

variable size with narrow, deep valleys, due to the complex tectonic structure of Apennine. Downstream of Ponte Liscione dam, Biferno Valley is almost rectilinear in the antiApennine direction and it seems that Biferno Valley was imposed on a right strike-slip fault (Fig. 2). In fact, the outcropping front of Apennine flysch along the northern fringe, hydraulic left of river Biferno, is slightly advanced, about 4$5 \mathrm{~km}$, compared to along the south one (Fig. 2).

The geomorphic characteristics of Biferno Valley downstream of Ponte Liscione dam have been analysed, on a medium-resolution ( $40 \mathrm{~m}$ square cells), grid-based DTM (Fig. 4). Due to the different geology downstream of Ponte Liscione dam, the geomorphic features of the valley sides are quite different from each other (Figs. 4 and 5a). The left flank is quite steep and high, while the right side of the valley is more gently sloping (about $5 \%$ ) up to a large plateau, where regressive and continental deposits crop out, i.e. Larino Plateau. It gently slopes (about $1^{\circ}$ ) toward the right side of Biferno Valley and NE toward the confluence of stream Cigno into river Biferno. The east bound of this plateau (Fig. 6) is the bow-shaped asymmetric valley of stream Cigno, which will be better detailed later. Larino Plateau is crossed by some narrow, deep (also more than $20 \mathrm{~m}$ ), bow-shaped stream valleys (Fig. 7), cutting regressive deposits till sub-Apennine grey-blue clays and draining towards Biferno Valley. It is noteworthy that even if these valleys are quite deep, they have no relevant alluvial fans at their outlets. 
a)

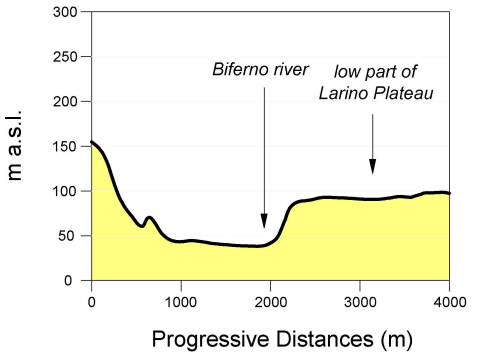

b)

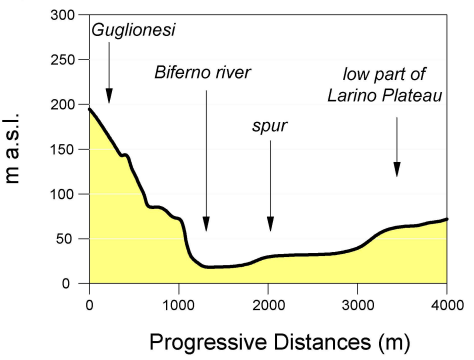

c)

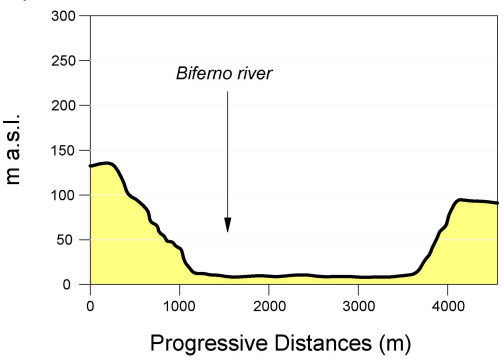

Fig. 5. Schematic cross section of river Biferno Valley at reaches (a) B-C and (b) D-E, and (c) G - Biferno river mouth.

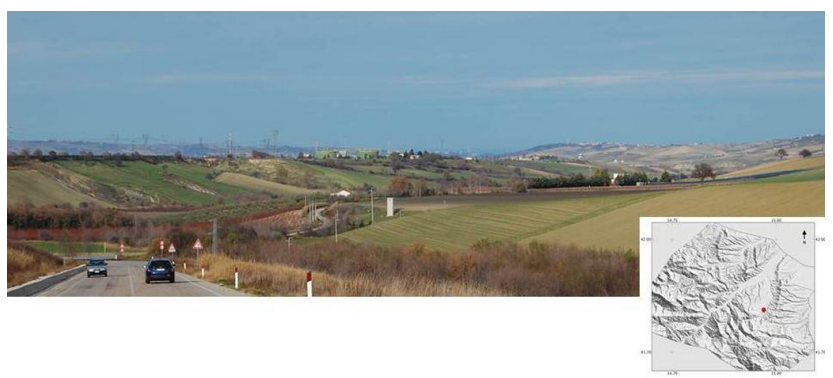

Fig. 6. View of the valley of river Cigno from downslope of Montorio dei Frentani hill. The bound of Larino plateau is evident, which that is the top hill of the left side flank of Cigno Stream valley. In the lower right-hand corner, the position from which the photo was taken is shown.

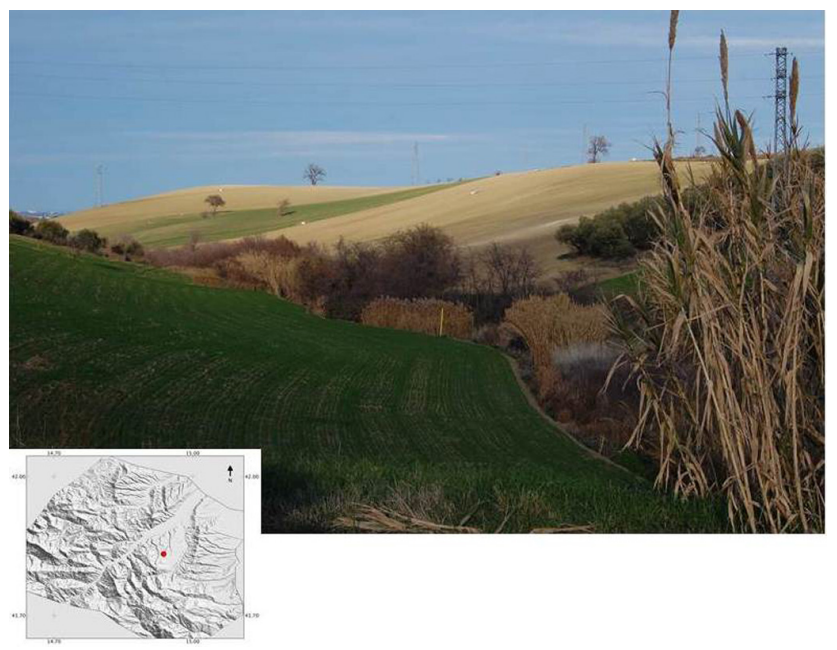

Fig. 7. View of one of the deep narrow valleys crossing Larino plateau. In the lower left-hand corner, the position from which the photo was taken is shown.

Stepping down towards the sea, the same foredeep deposits are on both sides of the valley: conglomerate regressive terraces (Qr) rest on the sub-Apennine grey-blue clays (Pa) (Fig. 2), and there is a general gradual smoothing of the shapes.

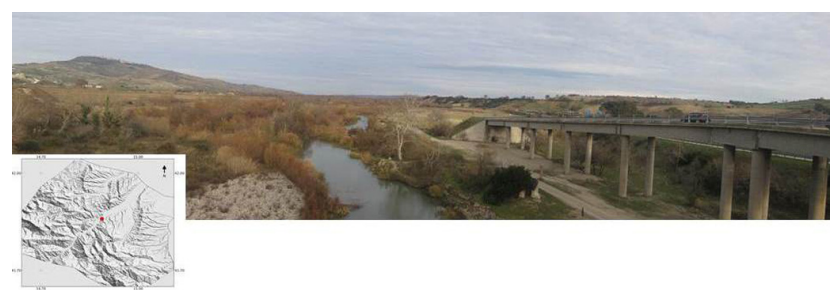

Fig. 8. View of river Biferno Valley downstream of Ponte Liscione dam. The asymmetry of the valley is evident. On the left side there is Guglionesi hill, while on the right side there is the lower part of Larino Plateau. In the lower left-hand corner, the position from which the photo was taken is shown.

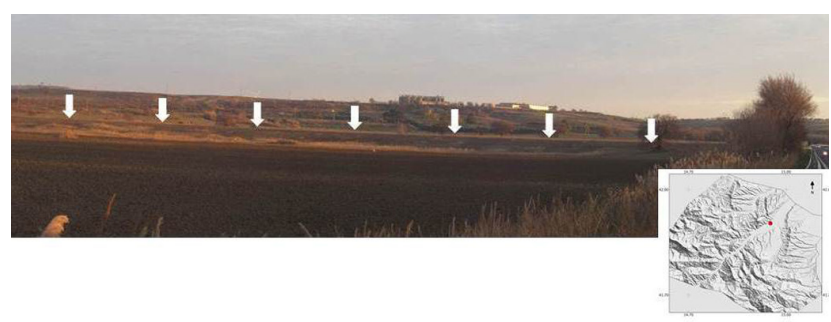

Fig. 9. View of the spur taken from the left side of the valley along the national road 647 . The white arrow indicates the front of the spur. In the lower right-hand corner, the position from which the photo was taken is shown.

However, looking at the two sides of the valley, they show different morphologies. The left flank of the valley (Figs. 5b and 8 ) is about $120 \mathrm{~m}$ higher and steeper (about $18 \%$ ) than the right one. Moreover, the left flank is affected by large retrogressive landslides up to Guglionesi town. On the right side of the valley, the morphology is gentler than the left flank, and the foredeep overconsolidated grey-blue clays and the closure deposits are advanced towards the centre of the valley creating a sort of morphological spur (Figs. 4, 5b, 8, and 9) that forced the river on the left side of the valley. After the confluence of stream Cigno into river Biferno, the valley widened, and the two flanks of the valley became quite similar (Fig. 5c). 


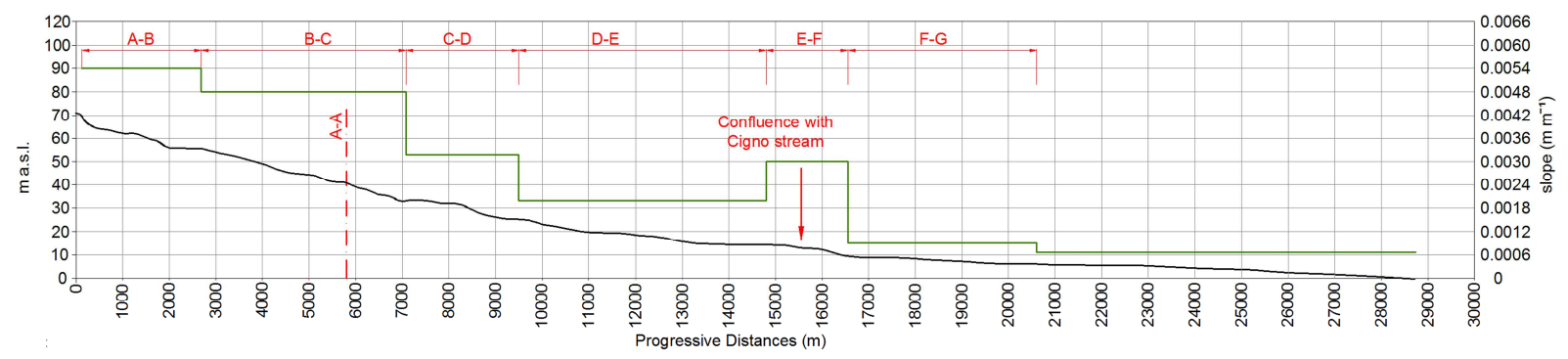

Fig. 10. Longitudinal profile of river Biferno downstream the dam of Ponte Liscione and hystogram gradient of the flow path measured every $200 \mathrm{~m}$.

\subsection{Peculiar characteristics of flow paths of river Biferno and stream Cigno}

Immediately downstream Ponte Liscione dam, the position of Biferno flow path (point A, Fig. 4) inside the valley is conditioned by the presence of the dam intake channel on the left side of river valley. Then, the river flows on the extreme right of the valley (reach B-C) as a consequence of the little asymmetry of the valley itself, with a moderate transversal slope toward the right side (Fig. 5a). Here, river Biferno flanks the toe of Quaternary deposits on the right side of the valley, with a gradient of $4.7 \%$ (Fig. 10). After point C, Biferno path suddenly drifts from the right side of the valley to the left one (reach C-D), lowering its slope to 3.3\%o (Fig. 10). The shifting is due to the aforementioned morphological spur (Fig. 4) characterized by consolidated deposits, which constitutes a "hindrance" to river Biferno flow. In order to bypass this morphological obstacle, river Biferno is forced to flow on the left side of the valley (reaches C-D and D-E, Figs. 4 and $5 b$ ). The gradient of these reaches, C-E, is generally lower than the upstream: $3.3 \%$ for the reach $\mathrm{C}-\mathrm{D}$ and $2 \%$ for the reach D-E (Fig. 10). Once passed the "morphological spur", there is a sort of step in the reaches E-F where the gradient is quite high $(3.1 \%$ ), and afterwards the flow path returns toward the centre of the alluvial valley towards the confluence with stream Cigno (Fig. 4). Downstream the confluence, river Biferno is characterized by a meandering path (Fig. 4), which allows the flow to dissipate the amount of energy gained as a consequence of the lower slope of D-E. After that, the river flows toward the sea, flanking the right side of the valley.

The analysis of old topographic and geological maps, released before the 19th century, allows for understanding that, over the last two centuries, river Biferno path remained unchanged in the study area. Despite the limits of survey techniques and graphical representation (Fig. 11), the topographic geological maps of 18-19th century (Germain et al., 1769; Rizzi Zannoni, 1809; Marzolla, 1932) provide significant insight about geomorphological features of river Biferno. During the last two centuries, the most relevant modifications involved the meandering path, while the river kept its main path almost unaltered (Figs. 11 and 12). Just

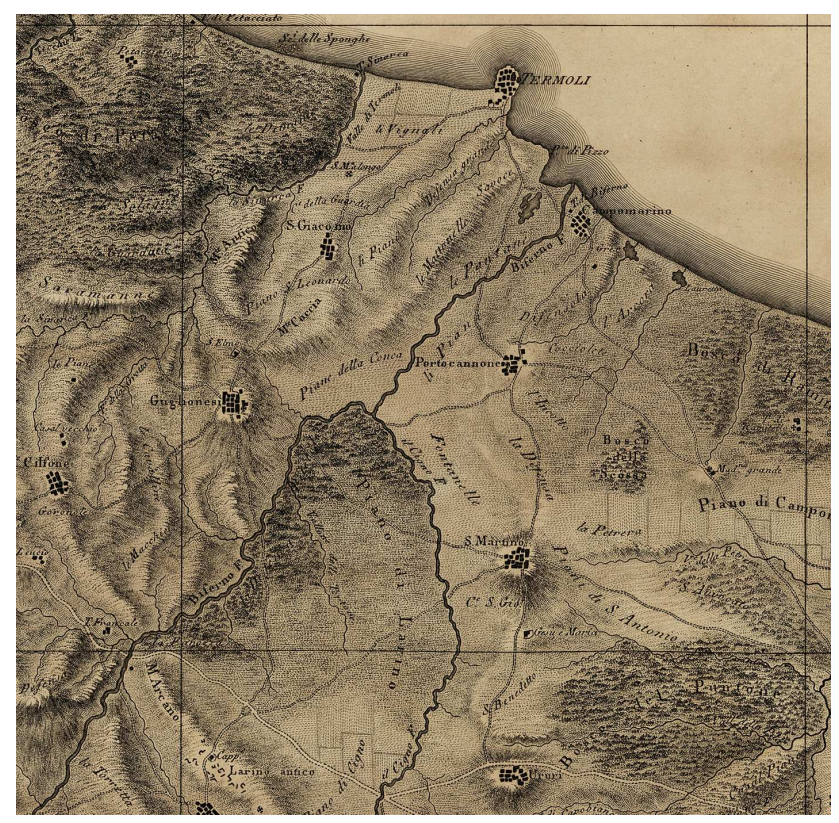

Fig. 11. Image of the studied area according to Atlante Geografico del Regno di Napoli (Geographical Atlas of Naples Kingdom) p 7 by Rizzi Zannoni (1809), Stamperia Reale, Napoli. It is evident how the river Biferno severely diverts in the area of Guglionesi just before the confluence with Cigno stream, giving evidence of the presence of the "spur" (http://www.mapsandimages.it/eMaps/main.htm, courtesy of M.I.D.A. informatica 1, Bergamo, and Hyperborea s.r.l., Pisa).

Biferno mouth moved back (Fig. 12), likely due to the decrease of solid transport, related to the presence of the dam, built during 1970s. The recent local specific modifications of river Biferno path with its narrowing and the creation of new terraced surface are described by Aucelli et al. (2009) and may be due essentially to the upstream presence of Ponte Liscione dam. The large meander inside the industrial area has now disappeared, probably after river engineering works related to the urbanization of the Termoli industrial area.

Therefore, the described strange flow path of river Biferno and the diversion of river path from side to side (reach CD) could be considered as an intrinsic feature, due to the 
geological structure of the valley and not the consequence of casual diversion of river flow path over the large valley. The curvature of this path is reverse with respect to the one associated with the transcurrent fault along Biferno Valley; therefore, it must be considered quite peculiar.

In addition, stream Cigno shows a particular flow path that deserves some consideration. It is upstream forced to flow among the deformed Apennine allochthonous nappes, and it follows a "double S" path (reach H-I, Fig. 4) with a quite steep stream slope $(22 \%$ ). The stream flows into a deep narrow valley, sided by flysch and marly units. After a straight reach (I-J) oriented WE, Cigno valley is characterized by a strange bow-shaped path (reach J-K, Fig. 4) cut among foredeep sub-Apennine grey-blue clay deposits. Along this bow-shaped reach, the valley has a strongly asymmetric section (Figs. 6 and 13). The right side is higher (about $120 \mathrm{~m}$ ) and is moderately sloping (about $7 \%$ ) with some morphological steps up to the crest of Ururi and San Martino in Pensilis, while the left side is characterized by a less high (less than $50 \mathrm{~m}$ ) but steeper (about $12 \%$ ) clayey scarp, up to a large morphological terrace (Larino Plateau). The flow path shows an apparent pseudo-meandering track (Fig. 4) on the reach $\mathrm{J}-\mathrm{K}$, despite its quite steep slope $(10 \%)$. As a consequence of all these anomalies, it seems unrealistic this valley can be modelled only by subsurface erosive processes, but its presence and shapes are due to more relevant geomorphic phenomena. On this premise, the stream network of the studied area shows several unusual peculiar features, not easily explained just on the basis of classic river hydraulic approaches.

\section{Analysis and interpretation}

The peculiar morphologies, geomorphic shapes and stream network flow paths in the area under investigation are here analysed according to a geology-based observational approach. It aims at interpreting them as due to the particular position of this area at the front of the chain where morphologies are strongly conditioned to be the effects of tectonic thrust, proposing a new hypothesis to the evolution of low Biferno Valley. The adopted observational approach is then integrated by a numerical geomorphological analysis focused on the medium-resolution, i.e. $40 \mathrm{~m}$ square cells, DTM, obtained using the technical regional maps of Molise, which were also used for the construction of the topography of the geological sections.

\subsection{The giant landslide}

The high and long (about $12-15 \mathrm{~km}$ ) scarp separating the crest of San Martino in Pensilis Ururi from Larino Plateau, where river Cigno flows at the toe, and the particular morphology of the whole area is here interpreted to be due to the presence of a giant, deep-seated landslide (Figs. 14 and 15)

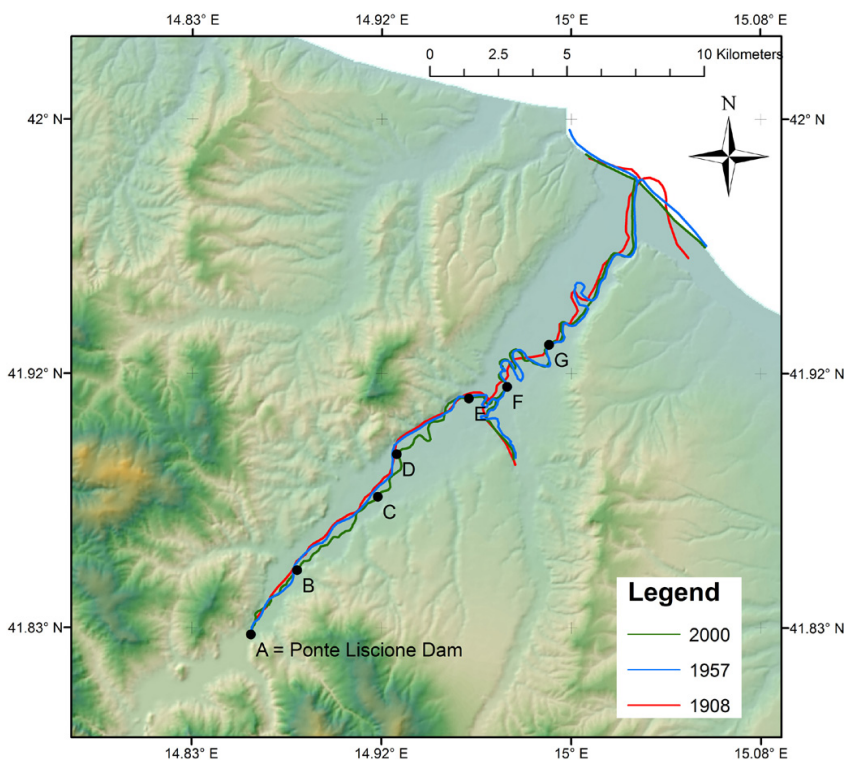

Fig. 12. Analysis of variation of Biferno plano-altimetric pattern downstream Ponte Liscione dam during the last century.

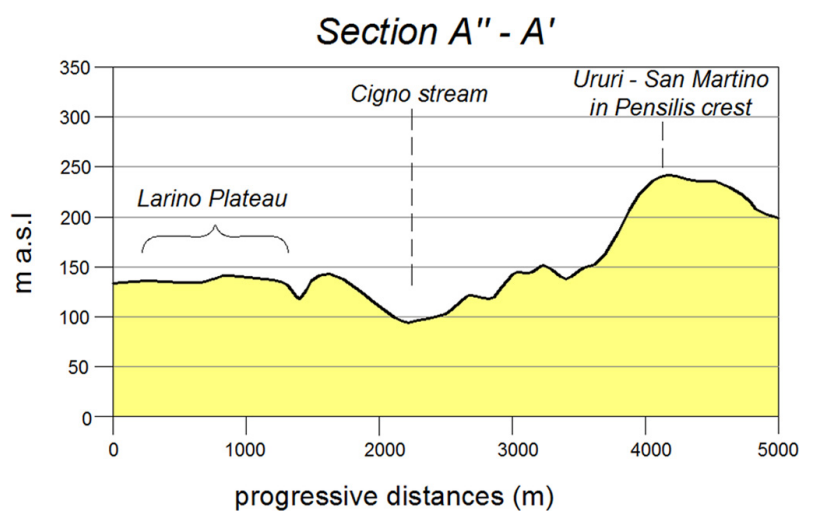

Fig. 13. Asymmetric valley of Cigno stream (extract A"-A' of geomorphological 2 section A-A'. See Fig. 2 for location of cross section).

spreading toward Biferno Valley. This affects the right side of low Biferno Valley downstream of Ponte Liscione dam, up to the confluence with stream Cigno, involving the entire area of Larino Plateau. Therefore, the high right flank of Cigno stream is here interpreted as the main scarp of the landslide, which opens the large trench where stream Cigno flows, whereas Larino Plateau constitutes the landslide body. Figure 14 shows a simplified sketch of shapes of the landslide masses. The width of the involved masses and the ancient age of the shapes made a detailed definition of the landslide bound difficult. Morphologies do not seem immediately related to a landslide, which normally generate disturbed shallow morphology. It is due to the fact that it moved as a sort of a huge rigid block spreading toward Biferno Valley along a failure zone at the contact between foredeep and 


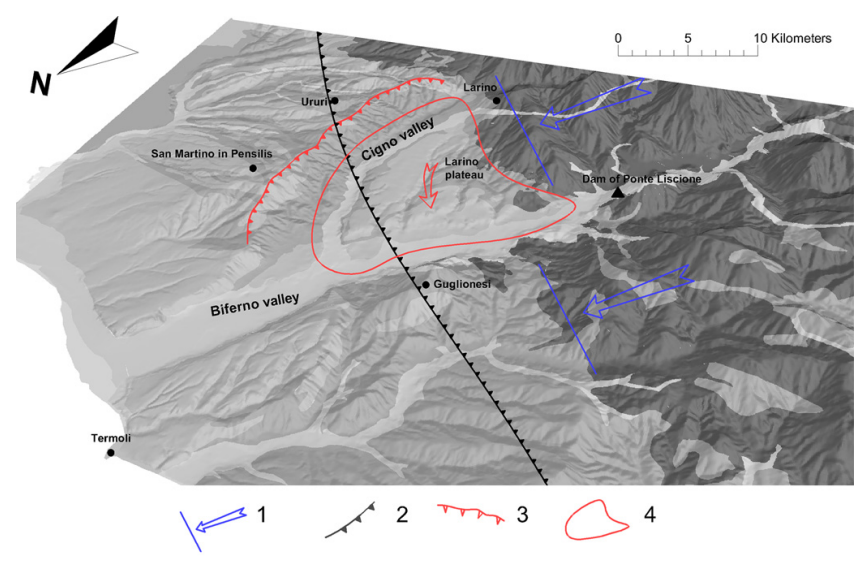

Fig. 14. 3-D view of the large landslide of the low Biferno Valley. The image is rotated anticlockwise about $150^{\circ}$, with respect to Fig. 2. 1 - differential stretching-out of outcropping Apennine front with a major advancing left side bank of Biferno Valley (dark-grey zones represent the allochthonous masses); 2 - buried front of the Apennine according to (Structural Model of Italy - CNR, 1992); 3 - main scarp of the landslide; 4 - schematic landslide body.

allochthonous masses (Fig. 15). The sliding masses are not completely disarticulated; therefore, it is not possible to observe a classical landslide deposit. On this premise, the landslide body is here outlined by the interpretation of the surface landforms (Figs. 14 and 15) and of the specific geological characteristics of the area. In particular, Fig. 15 introduces relatively simplified sections, since its purpose is to emphasize a macrophenomenon, i.e. the landslide, also because local features and details are not available and out of the focus of the work. It involves an area of about $40 \mathrm{~km}^{2}$ and a front of about $10 \mathrm{~km}$ (Fig. 14). The sliding masses are foredeep Plio-Pleistocene deposits, i.e. grey-blue clays, sands, conglomerates and closure regressive and continental deposits. The landslide body mainly moves on a basal disturbed zone, at the tectonic contact between allochthonous nappes and foredeep deposits (Fig. 15), due to the different mechanical behaviours of these two geological materials. The collapsed masses are quite homogeneous sandy clay masses, while their stiffness is due to drying and consolidation processes induced by the uplift. In fact when foredeep deposits come up as a consequence of the uplift, porewater pressure decreases and then effective stresses increase inducing consolidation phenomena and increase of stiffness. Allochthonous clay shales and varicoloured clays are denoted by quite low shear strength and stiffness (AGI, 1985; Cotecchia et al., 1992; D'Elia, 1991), due to the presence of varicoloured clay shales and bentonite clay, i.e. Faeto Flysch. Then failure may develop through the allochthonous clay shale, inducing a ductile behaviour mechanism (Petley and Allison, 1997). For tectonized bentonitic clay shales, movements of huge, deep-seated landslide masses with really low friction angle tilted to $2-3^{\circ}$ are documented (Shouldice,
1963; Carlisle, 1965). So the movement also with really low angle as a consequence of the presence of bentonitic clay shale does not appear to be strange.

Even if the main scarp of the landslide can be outlined, it is hard to provide an accurate delineation of its bounds besides quantifying its depth since no purposed in situ surveys are available. Anyway, the main purpose of this work is illustrating the peculiar mechanism of landslide at the front of the chain and its influence on landslide and flooding susceptibility of the territory. Then, estimation of its depth is attempted (Fig. 15) looking at the morphological characteristics of Cigno valley and Biferno Valley and on the basis of past experiences on other giant landslides in southern Apennine (Guerricchio and Melidoro, 1981; Guerricchio, 2000). The cross section (Fig. 15) is quite consistent with the depth of the buried, allochthonous clay shale nappes identified by oil exploration surveys at the boundary of the area at stake (VIDEPI Project) (Fig. 16) and with geological data about the position of buried Apennine front (Structural Model of Italy CNR, 1992; Patacca and Scandone, 2007).

The delineation of the south limit of the slide is complicated, since it is located at the transition zone between the chain and foredeep deposits, where the geological structures are strongly deformed. The deep narrow valleys crossing the central part of the slipped mass of Larino Plateau are quite parallel to Cigno stream (main scarp of the landslide), and they can be likely considered as secondary failures through the large landslide mass due to the different stiffness of the allochthonous and foredeep mass with respect to the slipped mass. These were generated during the movement of the masses involved by the deep gravitational collapse (Fig. 15). The morphological steps on the right side of the valley (Figs. 8 and 10) are here interpreted as secondary scarps. Figure 17 indicates the trends of the flow paths of river Cigno and of the deep narrow valleys crossing Larino Plateau. It shows that the geometric similarities of the attitudes of the considered streams are consistent with the advanced hypothesis. The "morphological spur" (Figs. 4, 5b, and 8) forcing river Biferno toward the left side of the valley (reach C-D) is the bulged toe of the landslide (Doglioni et al., 2013), constituted of consolidated clayey foredeep deposits, which cannot be easily eroded by river flow. This spur is the more advanced front of the landslide body; i.e. the spur is due to the compression of the toe of the landslide on its right side. In addition, the historical review evidences that the flow path of river Biferno remained unchanged over the centuries (Figs. 11 and 12). This means that its anomalous path is not simply related to the evolution dynamics of the river, but it is rather forced to that path by an external factor. Similarly, the meanders of river Biferno are always exactly located downstream of the spur. The alternative scenario of meanders related only to a low gradient would not justify their stable position. In addition, the strange bow path of stream Cigno can be explained as a landslide trench. The apparent meandering path of stream Cigno at the toe of the scarp of the landslide 


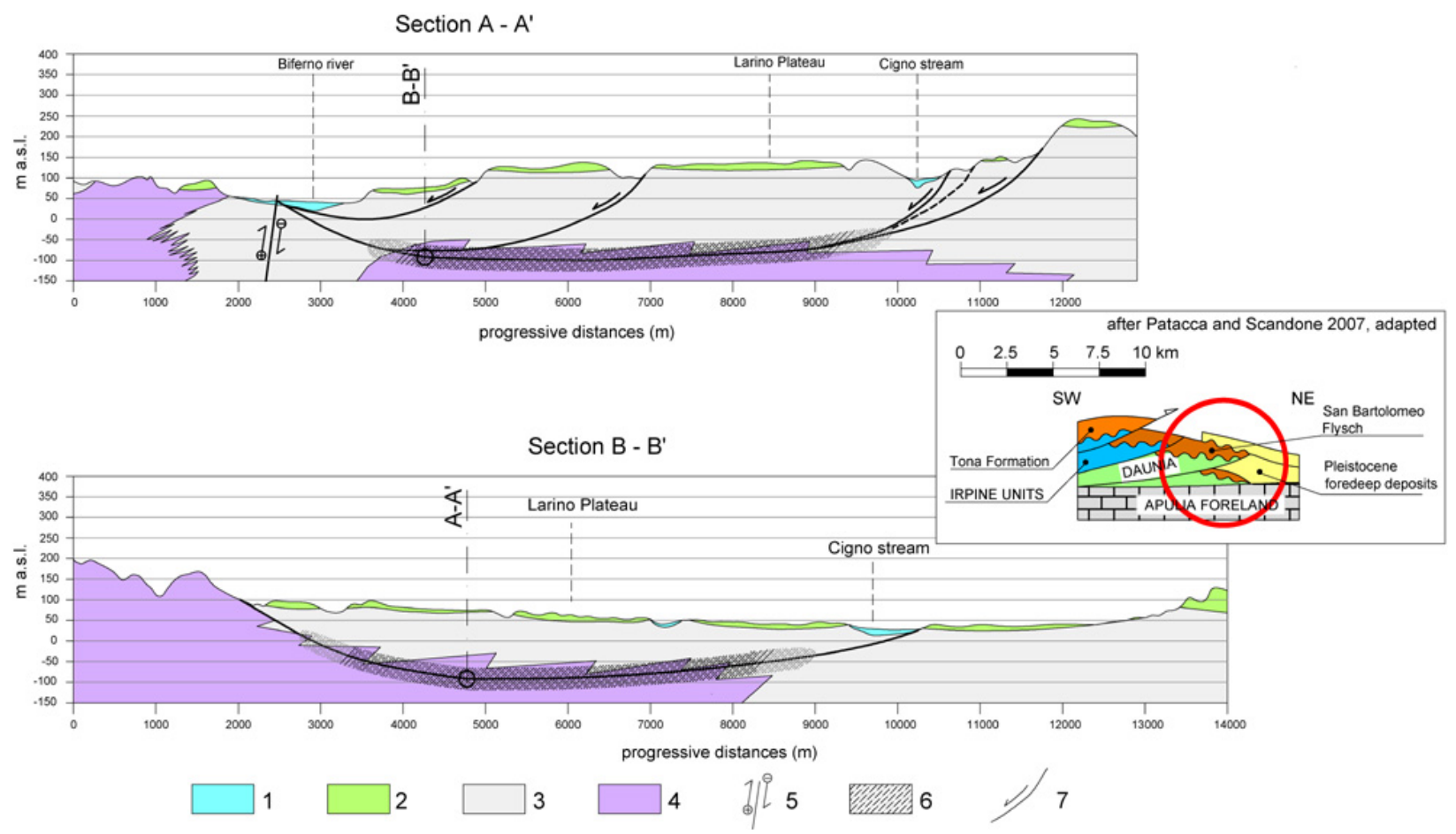

Fig. 15. Schematic geological cross sections. 1 - recent alluvium (Holocene); 2 - regressive deposits (Pleistocene); 3 - foredeep deposits: sub-Apennine grey-blue clays (upper Pliocene-Pleistocene); 4 - Apennine allochthonous nappe (Cretaceous-lower Pleistocene); 5 - right transcurrent fault; 6 - failure zone; 7 - schematized failure surface. Section B-B' is compared with the sketch of the geological relationships in the area. See Fig. 2 for location of cross section (after Patacca and Scandone, 2007, adapted and redrawn).
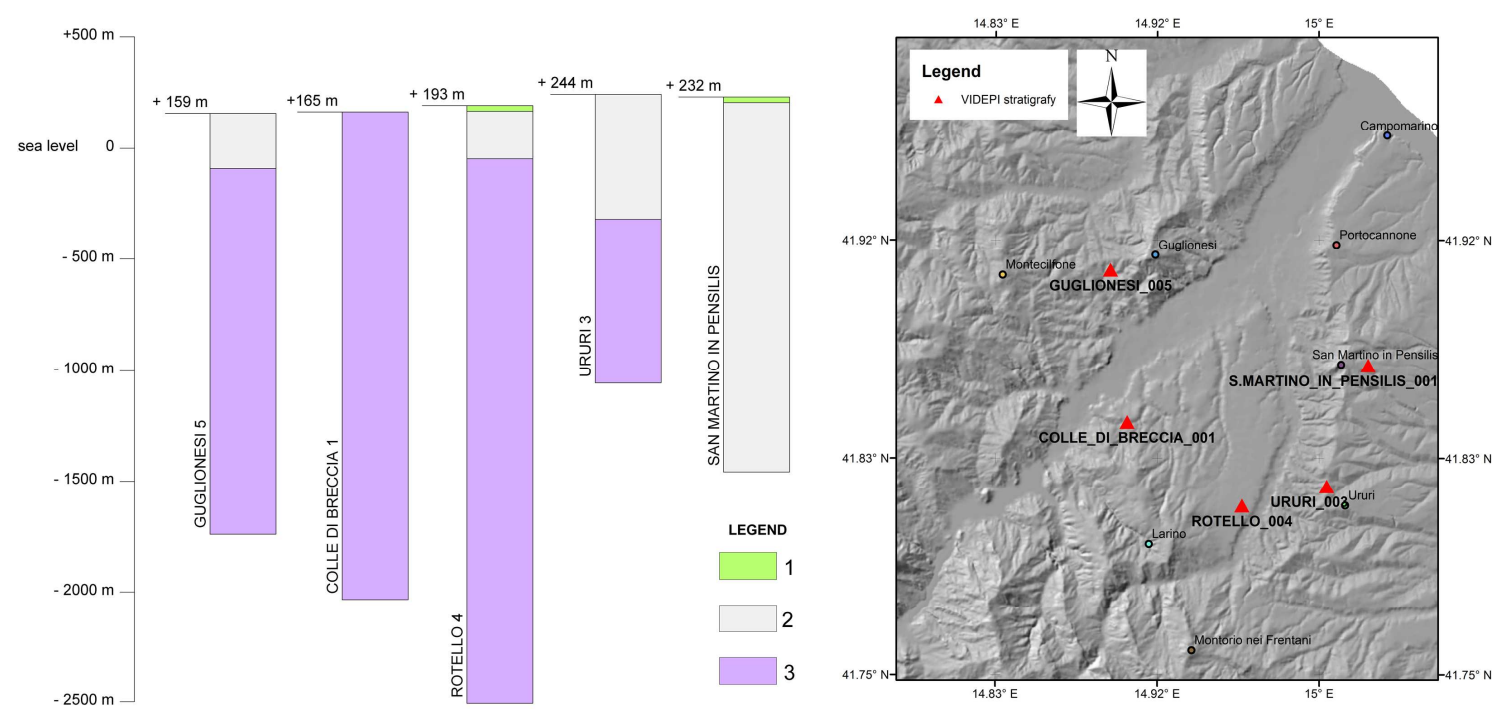

Fig. 16. Localization and schematic stratigraphic logs of some oil exploration surveys at the bound of the area at stake (VIDEPI Project). 1 - regressive deposits (Pleistocene); 2 - foredeep deposits: sub-Apennine grey-blue clays (upper Pliocene-Pleistocene); 3 - Apennine allochthonous nappe (Cretaceous-lower Pleistocene). 

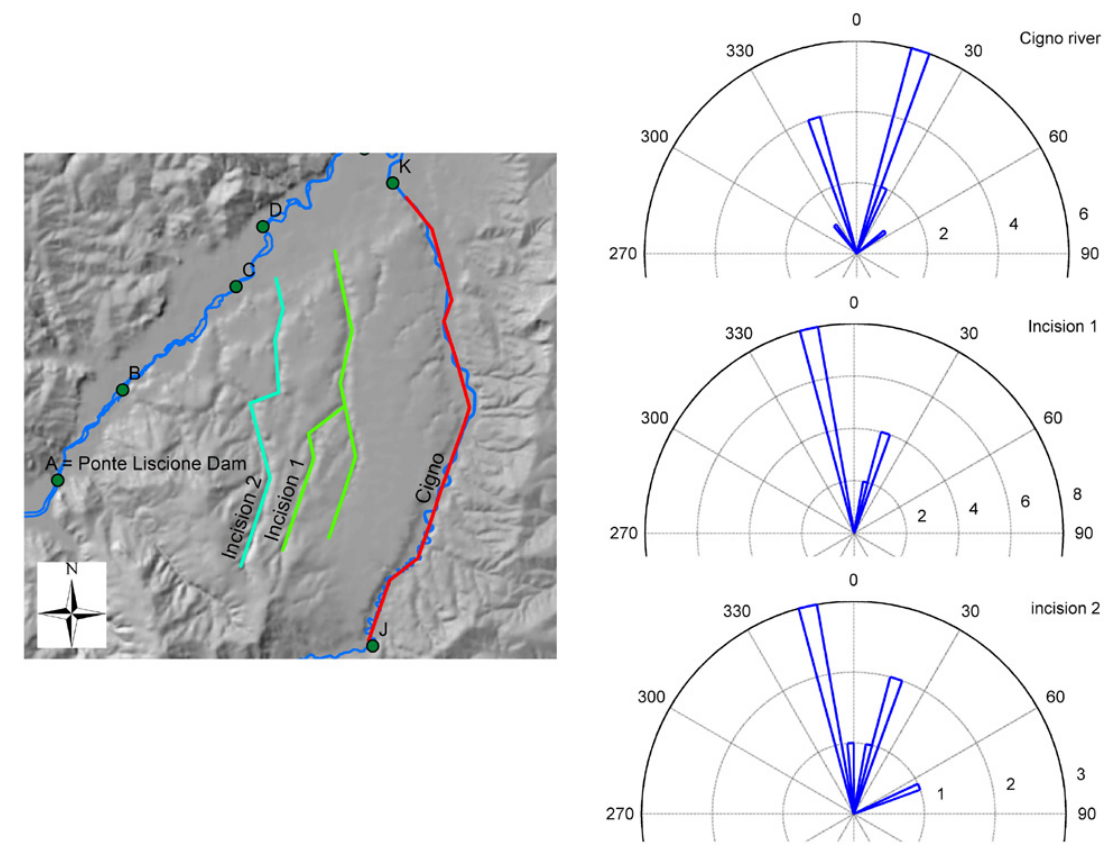

Fig. 17. Attitudes of river Cigno stream and of the main deep narrow valleys crossing Larino Plateau.

is due to the strongly irregular configuration of the scarp and to the presence of secondary landslides. It is a typical feature of the toe of the scarp of large landslides and/or deep-seated gravitational slope deformation (Guerricchio and Melidoro, 1981).

The genesis of the landslide may be due to deformations induced by the allochthonous, buried nappe of Apennine chain along the south fringe of Biferno Valley (hydraulic right of river Biferno). This likely uplifted foredeep deposits on the right side of the valley, thus generating the crest in the area of Ururi and San Martino in Pensilis. The south side of this crest gently slopes toward SE, while the north side could be collapsed toward Biferno Valley due to the absence of lateral confinement, generating the large, deep-seated landslide. The movement of the landslide is toward WNW, i.e. toward the valley, on the left side, with respect to the direction of Apennine thrust. The main driver is the tectonic stresses due to thrusts which push and uplift the foredeep deposits, making possible the movement of the landslide towards the unconfined side. The phenomenon was likely encouraged by the deepening of Biferno Valley during glaciation periods. Looking at the evolution of the uplift of southern Apennine as shortly outlined before, it is possible to assume that the landslide was activated during the last uplift period during Upper-Middle Pleistocene. Today the landslide is fossil.

\subsection{Geomorphological numerical analysis}

Two different geomorphic numerical analyses are here performed on the available DTM to support the introduced observational approach. These are based in the order on an adaptation of a 2-D continuous wavelet transform (Antoine et al., 2003; Bruun and Nilsen, 2003; Booth et al., 2009) aimed at constructing a hierarchical DTM, and on a slope and curvature analysis, focused on extracting tectonic features from the shallow topography of the stream network (Wobus et al., 2006). The analysis of the stream network focuses on the normalized steepness index, which can be correlated with the rock uplift rate according to what has been reported by Wobus et al. (2006), Whipple and Tucker (1999, 2002), Snyder et al. (2000), Kirby and Whipple (2001), and Lague and Davy (2003).

The 2-D wavelet analysis is aimed at obtaining a hierarchical representation of the DTM, which can provide evidence of anomalies or singularities of the land surface, which are not evident from the DTM as it is. In particular, 2-D wavelet transform preserves the average values of the elevation at different scales, and this is particularly suitable for grid-based DTM. More insight about the underlying specific features and math of wavelet is provided by Bruun and Nilsen (2003). Specifically, here a 2-D wavelet decomposition based on biorthogonal 1.1 wavelet function (Daubechies, 1992) is used. The target of the analysis is to map the detail coefficients of 2-D wavelet decomposition. These are related to the variations of the slope: in particular, an undisturbed profile of the local topography implies low numerical values (0-15) of the detail coefficients; on the other hand, changes of slope, i.e. disturbed profiles, of local topography imply high numerical values (more than 35) of detail coefficients. Therefore, detail coefficients of the wavelet transform provide a quantification of the change of slope along a direction, for each 
element of the DTM grid; more details are in Doglioni and Simeone $(2012,2013)$.

The DTM used for the elaboration covers a surface of about $1340 \mathrm{~km}^{2}$, from the coastline towards the Apennines. Wavelet decomposition was performed on 5 levels, starting from a $1174 \times 1612$ grid; the decomposition was done in the order along the horizontal and vertical direction, i.e. W-E and $\mathrm{N}-\mathrm{S}$. In particular level 1 image returned the most interesting image, presented by Fig. 18. The detail coefficients of the horizontal decomposition emphasize the Apennines on the south-west side of the image and their evolution towards the coastline. However, clearly visible in the central right part of the image is a large almost flat area on the right side of the valley (Larino Plateau), associated with detail coefficients ranging between 5 and 15 . The area is crossed by short deep valleys, where high detail coefficients (more than 3.5) are shown. Then it is bounded on the $\mathrm{W}$ and $\mathrm{W}-\mathrm{S}$ side by high values of detail coefficients ranging between 35 and 45 (Fig. 18). The left side of the valley shows a completely different scenario, where there are high detail coefficients, in particular close to the spur. The numerical analysis confirms the anomalous morphological structure of this zone. The flat zone on the right side of the valley represents the main body of the giant landslide, and the map of detail coefficients emphasizes its body as well as delineating its bound. In particular, its scarp and secondary failures in its mass are outlined by high values of detail coefficients. On the left side of Biferno Valley, high values of detail coefficients can be associated with the active landslides downstream the town of Guglionesi, which imply highly disturbed profiles.

A further geomorphological analysis based on the normalized steepness index analysis is here attempted starting from the extraction of fluvial profiles from the available DTM. The attempted analysis is aimed at evaluating the variations of the normalized steepness index along the profile of river Biferno (Fig. 10). As pointed out by Wobus et al. (2006), the local slope $S$ of a channel is represented by

$S=k_{\mathrm{S}} A^{-\theta}$,

where $k_{\mathrm{S}}$ is the steepness index, $A$ the drainage area and $\theta$ the concavity index. Here local variations of $k_{\mathrm{s}}$ and $\theta$ are investigated in order to get some information about local tectonics; more details about the theoretical background of this approach can be found in Wobus et al. (2006). In particular, in order to compare different reaches of the fluvial profile, the normalized steepness index $k_{\mathrm{sn}}$ is here used. In fact, since the steepness index is strongly related to the concavity index, a reference concavity $\theta_{\text {ref }}$ is introduced, which represents the regional average $\theta$ in undisturbed channel segment. The normalized steepness index is estimated as

$k_{\mathrm{sn}}=k_{\mathrm{s}} A_{\mathrm{cent}}^{\left(\theta_{\mathrm{ref}}-\theta\right)}$,

where

$A_{\text {cent }}=10^{\frac{\log A_{\max }+\log A_{\min }}{2}}$,

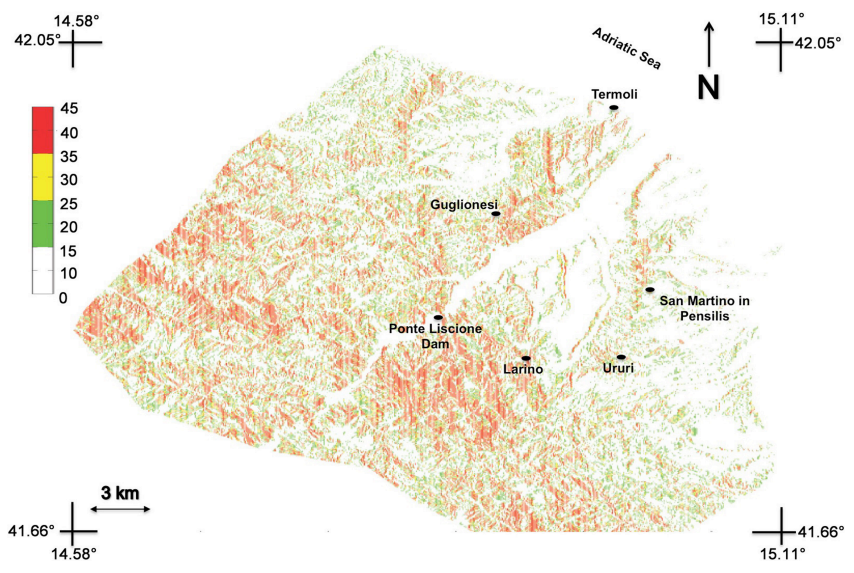

Fig. 18. Level 1 detail coefficients of the 2-D wavelet transform along the horizontal 2 direction (west to east).

where $A_{\max }$ and $A_{\min }$ are the bound of the reach of the profile analysed and $A_{\text {cent }}$ is the midpoint value for the analysed reach.

Assuming $\theta_{\text {ref }}$ equal to 0.45 , as suggested by Wobus et al. (2006), the values of $k_{\mathrm{sn}}$ for the reaches $\mathrm{A}-\mathrm{C}, \mathrm{C}-\mathrm{E}$, and E-G are on the order of $23.75 \mathrm{~m}^{0.9}, 13.32 \mathrm{~m}^{0.9}$ and $0.12 \mathrm{~m}^{0.9}$ (Fig. 19). These values are related to the rock uplift rate, according to the strategy proposed by Wobus et al. (2006). This emphasizes the higher rock uplift rate for the upstream reach, $\mathrm{A}-\mathrm{C}$, this reach being at the bound between chain and foredeep area. The value for the reach $\mathrm{C}-\mathrm{E}$ is about half of the previous one showing a lower, but not flat, rock uplift rate. Finally downstream, reach E-G, the normalized steepness index is very low according to the nature of this area, thus implying a negligible rock uplift rate. It is noteworthy that the segment $\mathrm{C}-\mathrm{E}$ of the river corresponds to the foredeep deposit area; however, it severely differs, in terms of rock uplift, from the final flat valley (see E-G). Figure 19 presents the fitting made on the river profile, and in particular the plot of the gradient vs. drainage area. This high value of $k_{\mathrm{sn}}$ in that specific reach $\mathrm{C}-\mathrm{E}$ and the irregular decreasing of $k_{\mathrm{sn}}$ values going downstream numerically confirm the anomalies of the flow path, related to the bulging due to the huge landslide toe.

Even if not exhaustive, the 2-D wavelet analysis shows in the order the presence of a large flat area, crowned by a scarp on its west and south-west side, while the analysis of the normalized steepness index shows an anomalous rock uplift rate along the river Biferno, just downstream the large flat area. These two analyses somehow provide two pieces of evidence of an anomalous scenario in the investigated area. This scenario is unique with respect to the investigated region, and it is fully consistent with the presence of a large, deep-seated landslide in the investigated area. 


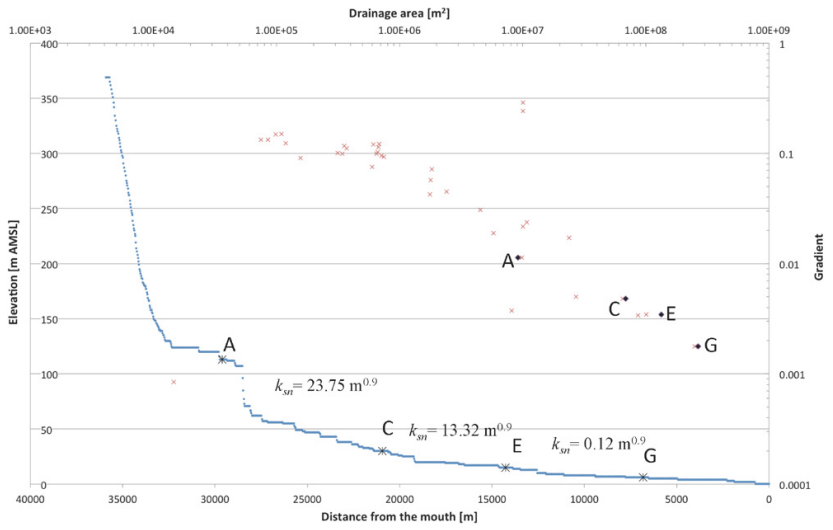

Fig. 19. Normalized steepness indexes evaluated on river Biferno profile and gradient of the profile vs. drainage area, log-log plot.

\subsection{Implications on flood and landslide susceptibility}

The presence of the landslide, and particularly of the "spur" connected to the landslide toe conditions, the hydraulic behaviour of river Biferno flow and indirectly affects both the hydraulic and landslide susceptibility of the studied area. To bypass the "spur", river Biferno is forced to flow on the left side of the valley (reaches C-D and D-E, Fig. 4) with a generally quite low slope (Fig. 10). Therefore, the flow increases its potential energy as a consequence of the lower gradient. Thus, after the confluence with stream Cigno, river Biferno has higher potential energy, gained bypassing the spur and as a consequence of inflowing discharge. This energy surplus is partly dissipated through a meandering path (reach F-G, Fig. 4). While ordinary discharges can regularly flow along the meandering path, extreme discharges cannot be easily canalized by that path, thus increasing the flood susceptibility of low Biferno Valley downstream of the meandering path. Then, during severe floods the peak discharge can break down the banks of the meandering ordinary path, and overflows all over the flat area of the lower catchment, where the Termoli industrial area is located (Fig. 4). This area has been historically prone to alluvial phenomena during the main floods of river Biferno. Important alluvial phenomena affected this area in 1940, 1962, and 1964, when, according to the data of the National Hydrographic Bureau, river Biferno discharge exceeded $1000 \mathrm{~m}^{3} \mathrm{~s}^{-1}$. The construction of riverbanks in 1970s and 1980s made this area available for new uses, but it did not remove the causes of its intrinsic susceptibility to floods related to the large landslide. This was clearly shown as a consequence of the large flood event with a peak discharge of about $2000 \mathrm{~m}^{3} \mathrm{~s}^{-1}$ that affected low Biferno Valley from 23-26 January 2003, as reported by Lastoria et al. (2006), and in databases about flooding phenomena (http://www.dartmouth.edu/ floods/Archives/2003sum.htm, http://www.protezionecivile.molise.it/index.php/ ristoro-danni/alluvione-gennaio-2003.html). During that event several factories located inside the industrial area of Termoli were seriously damaged, as reported by local and national newspapers of January-February 2003.

Flowing at the toe of the left slope (reach D-E), river Biferno causes severe erosive processes of that toe and, consequently, landslides, which retrogressively arrives up to Guglionesi town. A large series of scarps are recognizable on the left side of Biferno Valley, while the clayey masses involved with these phenomena appear severely dislocated (Fig. 4). In this area, 2-D wavelet analysis showed high values of detail coefficients (higher than 35), supporting the presence of a lot of slope anomalies related to local landslide scarps. A large, anomalous presence of active landslides, downstream Guglionesi town, was previously described by IFFI project (2007), which provides a detailed picture of the distribution of landslide phenomena in Italy. Moreover, the peculiar presence of multiple, spatially concentrated, active landslides in the area of Guglionesi was confirmed also by Righini et al. (2012). Using the technique of persistent scatter interferometry, they show that the right side of river Biferno Valley is subject to high displacements only in the area of Guglionesi. These displacements are so high that they could be related to specific landslide activity in this area, likely associated with severe erosive processes at the toe of the left side of Biferno Valley. Therefore, the characteristic flow path of river Biferno, pushed by the giant landslide, induces erosion at the toe of Guglionesi slope, increasing landslide susceptibility of that slope.

\section{Conclusions}

The uplift of foredeep deposits by tectonic deformation of chain belt and thrusting of allochthonous nappe deposits can generate uplift of foredeep deposits at the front of the chain and may cause giant landslides involving those deposits. These giant landslides may move on quite deep and low inclined slip surfaces along the contact with allochthonous, tectonized, scaly clay shales, due to the low shear strength of these deposits of the Apennine nappes thrusting the foredeep deposits. These giant, deep-seated, and not always evident, landslides can strongly affect geomorphological features of the internal part of foredeep domain, the hydraulic stream network and flood and landslide susceptibility.

A deep-seated, giant landslide was here identified in south Italy and evidenced by the geomorphological characteristics of low Biferno Valley downstream of Ponte Liscione dam. The tectonic action uplifted sub-Apennine grey-blue clays between river Biferno and stream Cigno, favouring the slipping of a huge landslide characterized by a $12-15 \mathrm{~km}$ long scarp, which involves the entire area of Larino Plateau, about $40 \mathrm{~km}^{2}$. The depth of the involved material is several tens of meters. The main morphological characteristics proving the presence of the large landslide are the great scarp at the toe 
(where stream Cigno is located), the lowering of the large Larino Plateau located between stream Cigno and Biferno Valley, and the features of the horizontal and vertical alignment of river Biferno. Also the quantitative geomorphological analysis confirmed the anomalies of that area supporting the proposed interpretation based on geological observations.

At the toe of the described large landslide, a morphological anomaly originated, i.e. "spur", on the right side of the valley, which generates a sort of weir, forcing river Biferno to deviate its course and to flow on the left side of the valley. This implies erosive processes at the toe of the left side of Biferno Valley and consequently a large number of landslides, retrogressively propagating up to Guglionesi town and conditioning the landslide susceptibility of the whole left side of the valley. Bypassing the spur, the flow decreases its hydraulic gradient, thus gaining energy that has to be dissipated by a meandering path downstream of the confluence with stream Cigno. While ordinary discharges flow regularly throughout the meandering path, highs cannot be easily canalized or overflow, spreading across the entire low valley. Then, the presence of the spur due to the landslide biases the susceptibility of the valley to flood phenomena.

The investigated huge landslide is considered as an interesting example showing how at the front of the main chains it is possible to have large landslides induced by tectonic deformations, affecting the main geomorphological features of large areas. These phenomena sometimes are not easily recognizable, but can strongly affect the morphology as well as the susceptibility to natural and environmental hazards of the area.

Acknowledgements. The authors are sincerely grateful to V. Valerio from IUAV Venice and M.I.D.A. Informatica 1 (Bergamo) and Hyperborea s.r.l. (Pisa) for the permission to use Fig. 11, and to an anonymous referee that made it possible to improve the manuscript.

Edited by: F. Guzzetti

Reviewed by: L. Tacher and one anonymous referee

\section{References}

AGI (Italian Association of Geotechnical Engineering): Caratteristiche geotecniche e stabilità dei pendii in formazioni strutturalmente complesse, in: Geotechnical Engineering in Italy, An Overview, International Society of Soil Mechanics and Foundation Engineering, Rome, Golden Jubilee Volume, 145-186, 1985 (in Italian).

Alexander, D. and Formichi, R.: Tectonic causes of landslides, Earth Surf. Proc. Land., 18, 311-338, doi:10.1002/esp.3290180403, 1993.

Amorosi, A., Bracone, V., Di Donato, V., Rosskopf, C. M., and Aucelli, P. P. C.: The Pliopleistocene succession between Trigno and Fortore rivers (Molise and Apulia Apennines): stratigraphy and Facies characteristics, GeoActa, 8, 1-12, 2009.
Antoine, J. P., Carrette, P., Murenzi, R., and Piette B.: Image analysis with two-dimensional continuous wavelet transform, Signal Process., 31, 241-272, doi:10.1016/0165-1684(93)90085-O, 2003.

Ascione, A., Cinque, A., Miccadei, E., Villani, F., and Berti, C.: The Plio-Quaternary uplift of Apennines chain: new data from the analysis of topography and river valleys in Central Italy, Geomorphology, 102, 105-118, 2008.

Aucelli, P. P. C. and Rosskopf, C.: Last Century valley floor modifications of the Trigno river (S. Italy): a preliminary report, Geogr. Fis. Din. Quat., 23, 105-115, 2000.

Aucelli, P. P. C., Cinque, A., and Robustelli, G.: Evoluzione quaternaria del tratto di Avanfossa Appenninica compresa tra Larino (Campobasso) e Apricena (Foggia), Dati preliminary, Il Quaternario, 10, 453-460, 1997 (in Italian).

Aucelli, P. P. C., Faillace, P. I., and Rosskopf, C. M.: Evoluzione geomorfologica del tratto finale del fondovalle del fiume Biferno (Molise): dal 1800 ad oggi, Memorie della Società Geografica Italiana, 87, 367-378, 2009 (in Italian).

Baron, I., Agliardi, F., Ambrosi, C., and Crosta, G. B.: Numerical analysis of deep-seated mass movements in the Magura Nappe; Flysch Belt of the Western Carpathians (Czech Republic), Nat. Hazards Earth Syst. Sci., 5, 367-374, doi:10.5194/nhess-5-3672005, 2005.

Booth, A. M., Roering, J. J., and Taylor Perron, J.: Automated landslide mapping using spectral analysis and highresolution topographic data: Puget Sound lowlands, Washington, and Portland Hills, Oregon, Geomorphology, 109, 132-147, doi:10.1016/j.geomorph.2009.02.027, 2009.

Brancone, V., Amorosi, A., Aucelli, P. P. C., Rosskpof, C. M., Scarciglia, F., and Di Donato, V.: The Pleistocene tectonosedimentary evolution of the Apenninic foreland basin betweenTrigno and Fortore rivers (Southern Italy) through a sequence stratigraphic perspective, Basin Res., 24, 213-233, 2012a.

Brancone, V., Amorosi, A., Aucelli, P., Ciampo, G., Di Donato, V., and Rosskpof, C. M.: Paleoenvironmental evolution of the Plio-Pleistocene Molise Periadriatic Basin (Southern Apennines, Italy): insight from Montesecco Clays, Italian Journal of Geoscience, 131, 272-285, 2012b.

Brückl, E.: Cause-effect models of large landslides, Nat. Hazards, 23, 291-314, doi:10.1023/A:1011160810423, 2001.

Brückl, E. and Parotidis, M.: Prediction of slope instabilities due to deep-seated gravitational creep, Nat. Hazards Earth Syst. Sci., 5, 155-172, doi:10.5194/nhess-5-155-2005, 2005.

Bruun, B. T. and Nilsen, S.: Wavelet representation of large digital terrain models, Comput. Geosci., 29, 695-703, doi:10.1016/S0098-3004(03)00015-3, 2003.

Carlisle, D.: Sliding friction and overthrust faulting, J. Geol., 73, 271-292, 1965.

Corsini, A., Borgatti, L., Cervi, F., Dahne, A., Ronchetti, F., and Sterzai, P.: Estimating mass-wasting processes in active earth slides - earth flows with time-series of High-Resolution DEMs from photogrammetry and airborne LiDAR, Nat. Hazards Earth Syst. Sci., 9, 433-439, doi:10.5194/nhess-9-433-2009, 2009.

Cotecchia, V., Salvemini, A., Simeone, V., and Tafuni, N.: Comportamento geotecnico delle unità Sicilidi ed Irpine affioranti nelle alte Valli dei Fiumi Sele ed Ofanto ad elevato rischio sismotettonico, Geologia applicata ed Idrogeologia, 27, 1-47, 1992 (in Italian). 
Crosta, G. and Clague, J. J.: Dating, triggering, modeling, and hazard assessment of large landslides, Geomorphology, 103, 1-4, doi:10.1016/j.geomorph.2008.04.007, 2009.

Daubechies, I.: Ten lectures on wavelets, Society for Industrial and Applied Mathematics (SIAM), 377 pp., 1992.

D'Elia, B.: Deformation problems in the Italian structurally complex clay soils, in: Proceedings of 10th European Conference on Soil Mechanics and Foundation Engineering, Florence, Italy, A.A. Balkema, ISBN 90-5410-005-2, 4, 1159-1170, 1991 .

Dewitte, O., Chung, C.-J., and Demoulin, A.: Reactivation hazard mapping for ancient landslides in West Belgium, Nat. Hazards Earth Syst. Sci., 6, 653-662, doi:10.5194/nhess-6-653-2006, 2006.

Doglioni, A. and Simeone, V.: Geomorphic numerical analysis based on wavelet transform Rend, $86^{\circ}$ Congresso Nazionale della Società Geologica Italiana, Arcavacata di Rende (Cosenza, Italy), 18-20 Settembre 2012, Rend. Online Soc. Geol. It., 21, 1111-1113, 2012.

Doglioni, A. and Simeone, V.: Quantitative geomorphological analysis based on wavelet transforms, in: Landslide science and practice, edited by: Margottini, C., Canuti, P., and Sassa, K., The Second World Landslide Forum, Rome, October 2011, Springer, 1, 257-264, 2013.

Doglioni, A., Galeandro, A., and Simeone, V.: A simple model for passive failure compression structure at the toe of landslide, in: Landslide Science in Practice, edited by: Margottini, C., Canuti, P., and Sassa, K., The Second World Landslide Forum, Rome, October 2011, Springer, 3, 177-182, 2013.

Doglioni, C., Tropeano, M., Mongelli, F., and Pieri P.: Middle-Late Pleistocene uplift of Puglia: An "anomaly" in the Apenninic foreland, Memorie della Società Geologica Italiana, 51, 101117, 1996.

Dramis, F. and Sorriso-Valvo, M.: Deep-seated gravitational slope deformations, related landslides and tectonics, Eng. Geol., 38, 231-243, doi:10.1016/0013-7952(94)90040-X, 1994.

Festa, A., Ghisetti, F., and Vezzani, L.: Carta Geologica del Molise Scala 1:100.000. Note Illustrative: Regione Molise - Presidenza della Giunta, Litografia GEDA, Nichelino (TO) ISBN 88902635-0-4, 2006 (in Italian).

Galadini, F.: Quaternary tectonics and large-scale gravitational deformations with evidence of rock-slide displacements in the Central Apennines (central Italy), Geomorphology, 82, 201-228, doi:10.1016/j.geomorph.2006.05.003, 2006.

Geological Map of Italy scale 1:100000, Maps 154 (Larino) and 155 (S. Severo), Servizio Geologico Italiano, available at: http://www.isprambiente.gov. it/it/cartografia/carte-geologiche-e-geotematiche/

carta-geologica-alla-scala-1-a-100000, last access: 19 April 2013, 1962-1963.

Germain, A. G., Perrier, L., and Rizzi Zannoni, G. A.: Quadro d'Unione della Carta Geografica della Sicilia Prima, map no. 2, Parigi (edited by: Valerio, V., Società Uomini e Istituzioni Cartografiche nel Mezzogiorno d'Italia, Firenze, 1993), 1769 (in Italian).

Guerricchio, A.: La fragilità del territorio dell'Italia centromeridionale desumibile da immagini da satellite, in: Proceedings of "X Congresso Nazionale dei Geologi - Conferenza Internazionale", Roma, 443-482, 2000 (in Italian).
Guerricchio, A. and Melidoro, G.: Movimenti di massa pseudotettonici nell' Appennino dell'Italia Meridionale, Geologia Applicata ed Idrogeologia, 16, 251-284, 1981 (in Italian).

Guerricchio, A., Melidoro, G., and Simeone, V.: Le grandi frane di Petacciato sul versante costiero adriatico (Molise), Mem. Soc. Geol. It., 51, 607-632, 1996 (in Italian).

Guerrichio, A., Doglioni, A., Galeandro A., and Simeone, V.: Deepseated gravitational slope deformation and hydraulic vulnerability of the low Biferno valley (Southern Italy), in: Geologically Active: Proceedings of the 11th IAEG Congress. Auckland, New Zealand, 5-10 September 2010, Taylor \& Francis Group, London, ISBN 978-0-415-60034-7, 683-689, 2010.

Guerricchio, A., Doglioni, A., and Simeone, V.: Tectonic gravitational deep-seated failures and macro-landslides in Scilla and Punta Pezzo area (Southern Calabria - Italy), $86^{\circ}$ Congresso Nazionale della Società Geologica Italiana, Arcavacata di Rende (Cosenza, Italy), 18-20 Settembre 2012, Rend. Online Soc. Geol. It., 21, 367-369, 2012.

Guzzetti, F., Cardinali, M., and Reichenbach, P.: The influence of structural setting and lithology on landslide type and pattern, Environ. Eng. Geosci., 2, 531-555, 1996.

Hutchinson, J. N.: General Report: morphological and geotechnical parameters of landslides in relation to geology and hydrogeology, in: Proceedings of the Fifth International Symposium on Landslides, Lausanne, edited by: Bonnard, C., Balkema, Rotterdam, 1, 3-35, 1988.

IFFI Project - Landslide inventory map, available at: http://193.206. 192.136/cartanetiffi/carto3.asp?cat=38\&lang=IT, last access: 19 April 2013, 2007.

Ippolito, F., D'Argenio, B., Pescatore, T., and Scandone, P.: Structural-stratigraphic units and tectonic framework of Southern Apennines, in: Geology of Italy, edited by: Squires, C., The Earth Sciences Society of Libyan Arab Republic, Tripoli, 317328, 1975.

Jaboyedoff, M., Couture, R., and Locat, P.: Structural analysis of Turtle Mountain (Alberta) using digital elevation model. Toward a progressive failure, Geomorphology, 103, 5-16, doi:10.1016/j.geomorph.2008.04.012, 2009.

Kellogg, K. G.: Tectonic controls on a large landslide complex: Williams Fork Mountains near Dillon, Colorado, Geomorphology, 41, 355-368, doi:10.1016/S0169-555X(01)00067-8, 2001.

Kirby, E. and Whipple, K. X.: Quantifying differential rockuplift rates via stream profile analysis, Geology, 29, 415-418, doi:10.1130/0091-7613(2001)029<0415:QDRURV>2.0.CO;2, 2001.

Koukis, G., Sabatakakis, N., Ferentinou, M., Lainas, S., Alexiadou, X., and Panagopoulos, A.: Landslide phenomena related to major fault tectonics: rift zone of Corinth Gulf, Greece, B. Eng. Geol. Environ., 68, 215-229, doi:10.1007/s10064-008-0184-8, 2009.

Lague, D. and Davy, P.: Constraints on the long-term colluvial erosion law by analyzing slope-area relationships at various tectonic uplift rates in the Siwaliks Hills (Nepal), J. Geophys. Res., 108, 2129, doi:10.1029/2002JB001893, 2003.

Lambeck, K., Antonioli, F., Anzidei, M., Ferranti, L., Leoni, G., Scicchitano, G., and Silenzi, S.: Sea level change along the Italian coast during the Holocene and projections for the future, Quatern. Int., 232, 250-257, doi:10.1016/j.quaint.2010.04.026, 2010. 
Lanzafame, G. and Tortorici, L.: Osservazioni geologiche sul medio e basso bacino del fiume Biferno (Molise, Italia centromeridionale), Geologica Romana, 15, 199-222, 1976 (in Italian).

Lastoria, B., Simonetti, M. R., Casaioli, M., Mariani, S., and Monacelli, G.: Socio-economic impacts of major floods in Italy from 1951 to 2003, Adv. Geosci., 7, 223-229, doi:10.5194/adgeo-7223-2006, 2006.

Marzolla, B.: Atlante Corografico Storico e Statistico del Regno delle Due Sicilie Reale Litografia Militare, Napoli, 1932 (in Italian).

National Hydrographic Bureau: Annali idrologici del Servizio Idrografico e Mareografico Nazionale, available at: http://www.acq. isprambiente.it/annalipdf/, last access: 19 April 2013.

Patacca, E. and Scandone, P.: Geology of the Southern Apennines, Bollettino della Società Geologica Italiana (Italian Journal of Geosciences), Special Issue, 7, 75-119, 2007 (in Italian).

Petley, D. N. and Allison, R. J.: The mechanics of deepseated landslide, Earth Surf. Proc. Land., 22, 747-758, doi:10.1002/(SICI)1096-9837(199708)22:8<747::AIDESP767>3.0.CO;2-\#, 1997.

Pizzi, A.: Plio-Quaternary uplift rates in outer zone of the central Apennines fold-and-thrust belt, Italy, Quatern. Int., 101-102, 2290-237, doi:/10.1016/S1040-6182(02)00105-2, 2003.

Rapisarda, F.: Landslide analysis in Apennine chain areas, Landslides, 4, 75-83, doi:10.1007/s10346-006-0066-8, 2007.

Rapisardi, L.: Tratti di neotettonica al confine molisano abruzzese, Geologia Applicata ed Idrogeologia, 13, 223-232, 1978 (in Italian).

Righini, G., Pancioli, V., and Casagli, N.: Updating landslide inventory maps using Persistent Scatterer Interferometry (PSI), Int. J. Remote Sens., 33, 2068-2096, doi:10.1080/01431161.2011.605087, 2012.

Rizzi Zannoni, G. A.: Atlante Geografico del Regno di Napoli - map no. 7, Stamperia Reale, Napoli (edited by: Valerio, V., Società Uomini e Istituzioni Cartografiche nel Mezzogiorno d'Italia, Firenze, Istituto Geografico Militare, 1993), 1809 (in Italian).
Savage, W. Z. and Varnes, D .J.: Mechanics of gravitational spreading of steep-sides ridges (sackung), Bulletin of the International Association of Engineering Geology, 35, 31-36, doi:10.1007/BF02590474, 1987.

Shouldice, J. R.: Gravity slide faulting on Bowes Dome, Bearpaw Mountains area, Montana, Bulletin of the American Association of Petroleum Geologists, 47, 1943-1951, 1963.

Snyder, N., Whipple, K., Tucker, G., and Merritts, D.: Landscape response to tectonic forcing: DEM analysis of stream profiles in the Mendocino triple junction region, northern California, Geol. Soc. Am. Bull., 112, 1250-1263, doi:10.1130/00167606(2000)112<1250:LRTTFD>2.0.CO;2, 2000.

Structural Model of Italy - CNR: Scale 1:500000, map no. 4, Progetto Finalizzato Geodinamica: Sottoprogetto Modello Strutturale Tridimensionale - C.N.R. (Italian National Research Council), 1992.

Vezzani, L., Ghisetti, F., and Festa, A.: Carta Geologica del Molise, Scala $1: 100000$, Selca, Firenze, 2004 (in Italian).

Vezzani, L., Festa, A., and Ghisetti, F.: Geology and tectonic evolution of Central-Southern Apennines, Italy, Geol. Soc. Am., Special paper, 469, 1-58, 2010.

VIDEPI Project: Visibility of petroleum exploration data in Italy, available at: http://unmig.sviluppoeconomico.gov.it/videpi/en/, last access: 19 April 2013.

Whipple, K. X. and Tucker, G. E.: Dynamics of the stream-power river incision model: Implications for height limits of mountain ranges, landscape response timescales, and research needs, J. Geophys. Res., 104, 17661-17674, doi:10.1029/1999JB900120, 1999.

Whipple, K. X. and Tucker, G. E.: Implications of sedimentfluxdependent river incision models for landscape evolution, J. Geophys. Res., 107, 2039, doi:10.1029/2000JB000044, 2002.

Wobus, C., Whipple, K. X., Kirby, E., Snyder, N., Johnson, J., Spyropolou, K., Crosby, B., and Sheehan, D.: Tectonics from topography: Procedures, promise, and pitfalls, Geol. S. Am. S., 398, 55-74, doi:10.1130/2006.2398(04), 2006. 